disregarding the greater area of prominence activity there displayed.

The white arrows in each of the five half suns are the plotted positions of the latitudes of the high and low prominence zones extracted from the table previously given, and show the mean positions of these zones from all the eclipses of each type. It will be seen that, for this single series of years, the arrows conform very well to the actual positions of the prominence zones.

Another attempt was made, but this time only using data for the second half of the same years as indicated in Fig. 3. In this case the prominence areas displayed, quite astonishingly, practically the same distribution in latitude, and thus exhibited the same forms. These computations suggested very strongly that an actual corona is really the sum total of a prolonged prominence action previous to its appearance at an eclipse.

It will be noticed in Fig. 2 that from the year 1925 all the curves have been continued up to the year 1940 by broken lines. These were inserted in 1925 to attempt to forecast the changes in the different solar phenomena from year to year. Comparing those curves with those now available up to the year 1929, it will be seen that they conform fairly well with the actual facts. It was at that time considered probable that the high-latitude prominence zone would be still in evidence in both hemispheres in the year 1929 in about latitude $80^{\circ}$, and would therefore give rise to a 'polar' type of corona for that year. The latitude of this zone was, however, not so accommodating, but only actually reached $52^{\circ}$ in the southern hemisphere and $44^{\circ}$ in the northern hemisphere, so that an 'intermediate' type of corona should have been expected and was actually recorded.

In the case of the next few total solar eclipses following that of 1930 , namely, those for the years $1932,1934,1936,1937$, and 1940, the forecast curves suggest that the 1932 corona may be of the 'equatorial' or on the boundary between an 'intermediate' and 'equatorial' type ; that the 1934 corona will be of the pure ' equatorial' type ; that the coronas of 1936 and 1937 should display an 'intermediate' type; and, finally, that the 1940 corona should be of the 'polar' type, owing to the position of the high-latitude prominence zone, which should then be in about latitude $70^{\circ}$ in both hemispheres.

It is satisfactory to record that, since my first communication to the Royal Astronomical Society in 1903 , showing that the prominences are responsible for the varying shape of the solar corona, this view has been endorsed by J. Evershed in 1908 and by Prof. Osten Bergstrand in 1930.

\title{
Gassendi and the Transit of Mercury.
}

$\mathrm{T}$ THREE hundred years ago, in November and December 1631 , the first accurately predicted transits of both Mercury and Venus took place, but only the transit of Mercury was observed. Kepler many years before had stated that Mercury would cross the sun's disc on May 20, 1607, and carefully but vainly watched for it. With the completion of the Rudolphine Tables in 1627, he again took up the problem of determining the times of transit, and in a small tract published in 1629, entitled "Admonitio ad Astronomos rerumque celestium studiosos, de miris rarisque anni 1631 phaenomenis ...", announced that Mercury would pass over the sun's disc on Nov. 7, 1631, and Venus on Dec. 6, 1631 . He announced at the same time that there would not be another transit of Venus before 1761 , but in this he was in error.

Only one person was fortunate enough to observe the transit of Mercury predicted by Kepler, and this was Gassendi, who then, at the age of thirty-nine years, was already recognised as one of the foremost French philosophers. Some years afterwards, Gassendi became professor of mathematics at the Collège Royale in Paris and by his lectures and writings did much to stimulate an interest in science, but in 1631 he was provost of the Cathedral at Digne, near which he was born. He had been a precocious youth, lecturing at the age of sixteen and at the age of twenty-one becoming a professor of theology and philosophy at Aix. Among his contemporaries he counted Mydorge, Mersenne, and Descartes, while among his correspondents was Galileo. He was in Paris at the time of the transit and he gave an interesting account of his observations to Schickhard, professor of mathematics at Tübingen, a man as learned as himself.

Speaking of his observations, Gassendi said : " The crafty god had sought to deceive astronomers by passing over the sun a little earlier than was expected, and had drawn a veil of dark clouds over the earth in order to make his escape more effectual. But Apollo, acquainted with his knavish tricks from his infancy, would not allow him to pass altogether unnoticed. To be brief, I have been more fortunate than those hunters after Mercury who have sought the cunning god in the sun. I found him out, and saw him, where no one else had hitherto seen him.'

Gassendi had arranged to see the transit by admitting solar light into a dark room through a small hole and receiving the image of the sun upon a white screen marked with a circle divided into sixty parts. He placed an assistant in a room above, to observe the altitude of the sun with a $2 \mathrm{ft}$. quadrant, and to signal. Nov. 5 and Nov. 6 were both rainy and overcast and the morning of Nov. 7 broke with the weather still changeable. But fortune favoured him in the end and he was able to observe the planet some time before it passed off the disc about 10.30 A.M. He calculated that the transit had taken five hours and had occurred about four and three-quarter hours before the predicted time.

The second predicted transit of Mercury occurred on Nov. 3, 1651, and was observed at Surat in India by the young English astronomer, Jeremy Shakerley, who had gone to that country for the purpose; while the third transit recorded by astronomers was

No. 3236, VoL. 128j

@ 1931 Nature Publishing Group 
on May 3, 1661. This was observed by Hevelius at Dantzig and by Huygens, Street, and Mercator in London.

Immediately after his observation of the transit of Mercury, Gassendi prepared to observe, if possible, the passing of Venus across the sun; for although this had been predicted to take place about sunset on Dec. 6, he considered that a possible error in the calculations might afford him the opportunity of seeing it. Dec. 4 and Dec. 5 were both stormy; Dec. 6 gave him glimpses of the sun, and the sun was visible all the forenoon of Dec. 7 . He saw nothing, however, and it was afterwards shown that the transit took place during the night between Dec. 6 and Dec. 7. Eight years later, the first recorded transit of Venus was observed, on Nov. 24. 1639, at Hoole, eight miles from Preston, Lancashire, by the young clergyman, Jeremiah Horrocks, and his companion, William Crabtree.

Gassendi died in 1655 at the age of sixty-three years and was buried in the Church of St. Nicolasdes-Champs, Paris; while Horrocks died in 1641 at twenty-three years of age and was buried in the ancient chapel of Toxteth Park, a monument being erected to him in Hoole Church in 1826 and another in Westminster Abbey in $\mathbf{1 8 7 4 .}$

\section{Obituary.}

Dr. David Starr Jordan.

$\mathrm{D}^{\mathrm{R}}$ R. DAVID STARR JORDAN, who died in California on Sept. 20, was for many years a prominent leader in the promotion of biological science and higher education in the United States. He was born at Gainsville, in New York State, on Jan. 19, 1851, and after attending a local school gained a scholarship at the newly founded Cornell University in 1869. There he graduated and began his active career as instructor in botany.

Jordan's first original papers, published in the American Naturalist, were on botanical subjects, but in 1873 he had the opportunity of attending the summer school of Louis Agassiz at Penikese, and henceforth his chief interest was in fishes. During the next few years he worked most industriously at systematic ichthyology, publishing several noteworthy papers, and in 1879 he was appointed professor of zoology in Indiana University. He was not only keen in research but also endowed with administrative ability, and in 1885 he became president of the University. There he remained until 1891, when he was elected first president of the Leland Stanford University in California, and rendered distinguished service to this new foundation until his retirement in 1916. As an acknow. ledgment of his work, he was eventually made chancellor emeritus of Leland Stanford University.

While occupied with academic duties, Jordan found time to take part in many other scientific and educational activities, and even in political discussions. From 1879 until 1890 he was closely associated with the United States Fish Commission, and in 1880 he was in charge of fishery investigations on the Pacific coast. In $1896-97$ he was the American representative on the commission for studying the fur seals in the Bering Sea, and in 1898 he published (with the aid of George A. Clark) an official "Report of Fur Seal Investigations". $\mathrm{He}$ was always active in organisations for the abolition of war. His varied reminiscences were published in 1922 in two volumes entitled "The Days of a Man"

Jordan's researches on fishes were chiefly concerned with the naming of genera and species and their systematic arrangement. He made a special effort to examine personally the older collections, to determine precisely the meaning of many of the earlier names which had been given without ade- quate definition. Helped by his pupils, who were usually joint-authors of his papers, he then proceeded to describe and name some hundreds of new forms, not only from North America, but also from Japan, the Philippines, and Hawaii. In 1883, with C. H. Gilbert, he published a "Synopsis of the Fishes of North America", and in 1896-1900, with B. W. Evermann, he prepared and published in four volumes a still more elaborate work on "The Fishes of North and Middle America". In 1905 he issued a more general "Guide to the Study of Fishes ", in two volumes. Between 1917 and 1920 he aided systematic ichthyology by preparing a list of all the genera of fishes named between 1758 and 1920, with an indication of the type species of each -a work published in four parts by Leland Stanford University. In 1923 he supplemented this by "A Classification of Fishes" in the same University's publications. In his later years, Jordan was stimulated, by the discovery of numerous fishes in the Tertiary diatomaceous earth of California, to describe and name fossil fishes both from North America and from Brazil, but the results were not very satisfactory.

Throughout his career Jordan's influence on the systematic study of fishes in North America was indeed great, and he has left several devoted pupils to continue and extend his work. $\quad$ A. S. W.

We regret to announce the following deaths:

Prof. James S. C. Douglas, Joseph Hunter professor of pathology in the University of Sheffield, on Oct. 30, aged fifty-two years.

The Rev. Dr. T. C. Fitzpatrick, president of Queens' College, Cambridge, and formerly a demonstrator in the Cavendish Laboratory, on Oct. 28, aged seventy years.

Dr. James W. Gidley, assistant curator of fossil mammals in the United States National Museum, on Sept. 26, aged sixty-five years.

Mr. Alfred J. Henry, senior meteorologist in the United States Weather Bureau, on Oct. 5, aged seventy-three years.

Prof. Guido Holzknecht, professor of medical radiology in the University of Vienna, and honorary member of the British Institute of Radiology, who was one of the pioneer workers in the application of X-rays to medicine, aged fifty-eight years. 